\title{
Just Mothering: Amy Coney Barrett and the Racial Politics of American Motherhood
}

\author{
H. Howell Williams (DD
}

Citation: Williams, H. Howell. 2021. Just Mothering: Amy Coney Barrett and the Racial Politics of American Motherhood. Laws 10: 36. https:// doi.org/10.3390/laws10020036

Received: 4 March 2021

Accepted: 8 May 2021

Published: 13 May 2021

Publisher's Note: MDPI stays neutral with regard to jurisdictional claims in published maps and institutional affiliations.

Copyright: (C) 2021 by the author. Licensee MDPI, Basel, Switzerland. This article is an open access article distributed under the terms and conditions of the Creative Commons Attribution (CC BY) license (https:// creativecommons.org/licenses/by/ $4.0 /)$.
Department of Social Sciences, Western Connecticut State University, Danbury, CT 06810, USA; williamsh@wcsu.edu

Abstract: Justice Amy Coney Barrett's nomination and confirmation featured frequent references to her role as a mother. This article situates these references within the trajectory of American political development to demonstrate how motherhood operates as a mechanism for enforcing a white-centered racial order. Through a close analysis of both the history of politicized motherhood as well as Barrett's nomination and confirmation hearings, I make a series of claims about motherhood and contemporary conservatism. First, conservatives stress the virtuousness of motherhood through a division between public and private spheres that valorizes the middle-class white mother. Second, conservatives emphasize certain mothering practices associated with the middle-class white family. Third, conservatives leverage an epistemological claim about the universality of mothering experiences to universalize white motherhood. Finally, this universalism obscures how motherhood operates as a site in which power distinguishes between good and bad mothers and allocates resources accordingly. By attending to what I call the "republican motherhood script" operating in contemporary conservatism, I argue that motherhood is an ideological apparatus for enforcing a racial order premised on white protectionism.

Keywords: Amy Coney Barrett; race; republican motherhood; American political development; conservatism

\section{Introduction}

As he introduced Amy Coney Barrett to the nation at a Rose Garden ceremony, President Donald Trump (2020b) praised her "unparalleled achievement, towering intellect, sterling credentials, and unyielding loyalty to the Constitution". In addition to these legal achievements, Trump noted that Barrett makes history as "the first mother of school-aged children ever to serve on the U.S. Supreme Court". Trump stressed that her commitment to family added value to her role as a judge, describing her as "more than a stellar scholar and judge; she is also a profoundly devoted mother" (emphasis added). The president's introduction demonstrated motherhood to be a dominant trope in the confirmation of Barrett to the Supreme Court. Her appearance before the Senate Judiciary Committee featured numerous references to her role as a mother, as well, and media outlets highlighted the significance of motherhood in the hearings (e.g., Block 2020; Cantor 2020; Miller and Gupta 2020; Keating 2020).

Political references to motherhood, or what Grace Deason et al. (2015) call "politicized motherhood", are not new, of course, and women across American history have deployed motherhood to achieve various political goals (Greenlee 2014). Race has always played a pivotal role in delimiting the relationship between mothers and the state, which tends to valorize the practices of white middle-class mothers and scrutinize nonwhite mothering. In the context of motherhood as a site of racial differentiation, Barrett represents the institutionalization of a political subjectivity premised on the values and norms of white middle-class motherhood. This development is made more significant in the context of the Trump presidency, which represented a new chapter in the evolution of racial orders in American politics and the ascendance of white protectionism in the contemporary Republican Party (Smith and King 2020). Trump's white protectionism and Barrett's 
motherhood politics are not coincidental phenomena; instead, we should regard them as co-constitutive. In what follows, I argue that white motherhood is an important ideological apparatus for enforcing a racial order premised on protecting whiteness from challenges posed by an increasingly racially diverse polity.

In this article, I attend to the racialized dynamics of Barrett's rise through a sustained engagement with motherhood in American political development. This analysis reveals how conservatives seek to institutionalize a white-centered racial order through what I call the "republican motherhood script". This script entails a set of interlocking claims about politicized white motherhood:

- First, white motherhood's political salience is premised on a moral claim about the virtuousness of mothering. Historically, "republican motherhood" provided an important source of political agency for some women, but only inasmuch as their mothering was deemed sufficiently virtuous and only in the context of mothering practices carried out within the home. "Virtuous" motherhood was always a racialized subjectivity, however, as the white heteronuclear family was associated with the values of good republican citizenship. Though articulated differently in specific historical contexts, the resultant racialized hierarchy of good and bad mothers has remained durable across time;

- Second, articulated through references to the quotidian aspects of homemaking and childrearing, politicized white motherhood deploys a domestic narrative that is grounded in the experiences of middle-class family life. Recalling the distinction between public and private spheres, such references seek to differentiate the acts of mothering from the less virtuous practices of political and economic activity. These references are selectively deployed to highlight the significance of practices such as loving and supporting children or household management while downplaying messier and more monotonous tasks, distancing white mothers from the activities traditionally associated with domestic laborers. Such references have the practical effect of erasing the experiences of people of color and working-class mothers for whom the domestic sphere has always been both a target of state surveillance as well as a site of coerced and/or wage labor;

- Third, politicized white motherhood entails an epistemological claim about the specific types of knowledge and ways of knowing derived from being a mother. The epistemological dimensions of motherhood stress a shared understanding of the nature of political problems and the most desirable solutions to them. Such references leverage the ubiquity of carework that has historically been assigned to women to create a shared grammar of domestic practices. To recall, however, domestic work has never been experienced by all women identically across history. As such, these epistemological claims reproduce the universality of white mothers' experiences and thereby marginalize the experiences of mothers from less privileged backgrounds;

- Finally, and following from these observations, universalized white motherhood operates as a modality of power that conceals itself as apolitical. The quotidian elements of mothering are presented as both more virtuous and less controversial than conventional politics. Based on a shared epistemology of motherhood ostensibly common to all mothers, though practically specific to white middle-class mothers, mothering practices are treated as outside of political debate. As generations of feminists have demonstrated, however, even the most mundane aspects of private life are racially coded, gendered, class-inflected, and therefore subject to political contestation.

Taken together, these claims deploy universalized motherhood as a political tool through which contemporary conservatives seek to entrench a white-centered racial order. In what follows, I trace the evolution of these dynamics through American political development before turning to a close reading of Amy Coney Barrett's confirmation. This analysis demonstrates how motherhood enacts the racial dynamics of modern American conservatism. 


\section{Motherhood in American Political Development}

Motherhood's significance is an enduring feature of American politics, although the relationship between motherhood and the state has changed over time in response to economic, social, and cultural factors (Greenlee 2014). As a body of scholarship specifically attuned to the dynamics of flux and stasis in the organization of the state, American political development (APD) provides important insights into the production of contemporary motherhood politics. Some scholars of APD underscore the centrality of race as an organizing principle in America's governing institutions, characterizing change as a result of competition between rival groups of policy coalitions held together by racial logics, or what King and Smith (2005) call "racial orders". A burgeoning subset of APD research has focused on the family as an institution at the center of organizing racial orders across time (Alphonso 2018; Novkov and Nackenoff 2020; Strach 2006). Motherhood, being at once a prescriptive articulation of women's behavioral norms as well as a site of state policy intervention, is an important site for coalescing racial ideologies. Representing what Michael Omi and Winant (2014, p. 125) call a "racial project" that is "simultaneously an interpretation, representation, or explanation of racial identities and meanings, and an effort to organize and distribute resources (economic, political, cultural) along particular racial lines", motherhood contributes to the coherence of racial categories by linking the signification of racial difference with the structural conditions of racially stratified life. Because these dynamics are historically contingent, the ideational content of motherhood politics shifts over time. Two broad sets of claims, or scripts, about the political significance of motherhood remain persistent across this historical variation, and these maternal scripts have emerged alongside and contributed to the coherence of racial orders.

\subsection{Republican Motherhood Script}

According to what I call the republican motherhood script, motherhood derives its political significance from women's proximity to future citizens, that is, American children. In the early days of the republic, leaders were concerned about promoting and protecting the civic virtue necessary to sustain a system of self-government, and women were seen as an ideal conduit for securing a virtuous future (male) citizenry (Vandenberg-Daves 2014). Reformers developed institutions such as women's colleges that could support women in their roles as mothers and educators and help them to inculcate the values of "republican motherhood" (Kerber 1976). Arising out of the need to find a political role for women that would not grant them full participation in political life, republican motherhood was a theory of political agency derived from women's familial responsibilities. Reformers stressed the importance of civic virtue among citizens but were wary of tasking a government body with the responsibility of civic education; an expansive government operation was anathema to the principles of self-government. Instead, private relations were seen as a more appropriate terrain for instilling virtue, and no institution was better suited for the task than the emerging bourgeois nuclear family. Her role within the family gave the mother a unique power to contribute to the longevity of the young nation. "Dedicated as she was to the nurture of public-spirited male citizens", Linda Kerber (1980, p. 11) writes, the republican mother "guaranteed the steady infusion of virtue into the Republic". Not simply a passive, docile agent or servant to the patriarchal father, the republican mother held the key to the future of a virtuous citizenry.

By highlighting work performed within the home, the republican motherhood script reified the distinction between the public and private spheres. In the 19th century, Alexis de Tocqueville noted a prevailing public opinion that sought "to contain women within the restricted sphere of domestic business and duties and to forbid them to step beyond it" (De Tocqueville 2003, p. 687). Women's magazines proliferated during this time, introducing women to the burgeoning science of good housekeeping. Religious teachings and popular culture stressed a woman's selfless love and devotion to God and family as her ultimate calling, contributing to what historians call the "cult of true womanhood" (Welter 1966). This set of rules and norms kept women in the private sphere of the home by stressing 
domesticity and piety. Though she may never leave the home, Tocqueville wrote, and though she is "in certain respects very dependent within it, nowhere does she enjoy a higher status" (p. 700).

The Tocquevillian "higher status" conferred to women within the home was almost exclusively the province of white mothers, however, and the differences in how white and Black women experienced domesticity were drastic. The domestic tranquility of the white bourgeois home was the product of labor performed by people outside the nuclear family, often women of color, through either forced or menial wage labor. The ability to successfully manage the home as a site of economic activity was an important marker of middle- and upper-class white womanhood in the 19th century (Kerber 1980). The monotonous tasks of homemaking (e.g., cleaning and wet nursing) featured less prominently and were frequently performed by enslaved or indentured servants in upperclass households (Jones 2010). Particularly in the South, white motherhood provided a tool for enforcing racial divisions, and white slave-owning women used their roles as mothers to instruct their children on how to treat and punish enslaved people (Jones-Rogers 2019). Contrary to the republican script's distinction between public and private life, "the home" was only a place of "privacy" for a select group of mostly white women whose homes evaded the surveilling eye of social and political regulation. For many other women across American history, the white home has not been a space separated from economic activity; it has been a racialized space in which economic activity is performed amid the threat of violence or deprivation. The republican script's division between public and private was thus meaningful only in the context of white family life, as non-white mothering was deemed insufficiently virtuous. As Hazel Carby (1987, p. 20) notes, "two very different but interdependent codes of sexuality operated in the antebellum South, producing opposite definitions of motherhood and womanhood for white and black women[.]"

The disparities between white and Black mothers were not merely ideological; they also provided a legal rationale for enforcing inequality between white and Black families. Alphonso and Bensel (2020) examine the role of Antebellum Louisiana courts in enforcing the color line through family regulation. Because motherhood entails an irrefutable biological connection between parent and child, courts often looked to the physical features of a mother to determine a child's racial makeup. In so doing, Alphonso and Bensel (p. 111) argue, "the physicality of mothers was far more closely inscribed in physical constructions of racial identity based on descent and thus in the biological imagination of whiteness and blackness". Similarly, fears over interracial marriage shaped state institutions in the postReconstruction South (Novkov 2008). While lawmakers gave passing glances to programs intended to "establish[] the integrity of black family units and encourag[e] blacks to form relationships that were separate from but structurally parallel to the private elements of white marriages, the principal focus in early litigation was to elevate and protect the white family as the cornerstone of the state", Julie Novkov writes (p. 24). Despite the multiple valences of racial orders, scholars of American political development agree that race was a crucial factor in determining which families deserved protection by the state and which deserved to be surveilled and disciplined (Novkov and Nackenoff 2020). Said another way, the tension between white and Black mothering generated the racial difference it purported to explain.

The republican script contributed to the coherence of a white supremacist racial order in the 19th century. Prioritizing the mothering practices associated with the white bourgeois family entailed downplaying or erasing the domestic work performed by nonwhite and lower-class labor. The disparities between white and Black motherhood were not a byproduct of the prevailing racial system. Instead, they were a tool for upholding white superiority and Black subjugation.

\subsection{Materialist Motherhood Script}

Whereas republican motherhood prioritizes women's role in the home and reifies the divide between the public and private spheres, an alternative maternal script stresses the 
importance of bringing "women's work" into the social world and transgressing separate spheres thinking. Because it seeks to improve the material conditions that shape social life, I refer to this as a materialist maternal script. Materialist scripts differ from republican scripts in how they account for and seek to address social problems. Rather than a crisis of virtue, the materialist script identifies unequal access to resources as a key driver of social inequality. The materialist script has been an important driver of progressive reforms and state building (Mink 1995; Skocpol 1992). Perhaps the clearest example of the materialist script in action was the settlement movement of the late 19th and early 20th centuries. Social reformers such as Lillian D. Wald and Jane Addams leveraged their roles as women to push for more progressive social policies. Faced with dramatic changes driven by industrialization, immigration, and urbanization, this generation of reformers rejected the notion that a woman's political role should be cordoned to domestic activities performed within the home. Instead, these domestic responsibilities provided a template for how women should bring about reform within the political sphere (Muncy 1991). Known as "municipal housekeeping", this approach conceptualized the industrialized city as a home that required similar upkeep. Whereas the care for workers, children, and the infirm had previously been performed in the home, reformers sought to reimagine the American city as performing those functions. Wastewater treatment, mutual aid, safe working conditions, and building codes were just a few of the policies reformers presented as matters of good homemaking on an urban scale (Chadsey 1915).

While the redistributive impulse animating the materialist script can be conducive to an egalitarian racial order, the history of the settlement movement demonstrates the limitations of pursuing racial equality through white motherhood politics. Figures such as Addams were cognizant of the deleterious impact of racism on American life, and the integrationism embodied by the settlement house provided a model for achieving an ethnically pluralist society. However, most settlement reformers were chiefly concerned with integrating newly arrived European immigrants, and most therefore turned a blind eye to the issues facing African Americans (Lasch-Quinn 1993). Instead, as Elisabeth LaschQuinn (1993) shows, it was the rise of mutual aid and community organizations among Black urban dwellers as well as interracial religious outreach programs that upheld the progressive promise of the settlement movement for Black families (see also Higginbotham 1994). Shut out of both the mainstream settlement movement and traditional political channels, elite Black women devised their own maternalist politics. Blending republican and materialist themes, they drew attention to the private sphere of childrearing as an important site for intervention while also underscoring the social nature of racial and economic inequality (Roberts 2004). Numerous subsequent movements have featured calls for deeper state investment in public welfare and racial justice using a materialist script grounded in the experience of Black motherhood (Lawson 2018).

The materialist script deploys motherhood to raise awareness of the material conditions affecting families and to push for better social programs that can improve those conditions. Materialist interventions in the early 20th century were important antecedents to the expansion of federal welfare, and they contributed to the uniquely maternalist nature of the American welfare state (Mink 1995; Skocpol 1992). As welfare became racialized and associated with Black single motherhood in the post-war era, however, a resurgent republican motherhood predicated on moral traditionalism and opposition to government civil rights programs sought to reassert the separation of public and private spheres.

\section{Motherhood in 20th-Century Conservatism}

Motherhood has played an important role in the development and durability of contemporary conservatism. In the post-war period, concern over liberalizing social norms fused with anti-communism and a defense of Americanism among American conservatives. Cold War anti-communism and opposition to feminist and civil rights advancements were instrumental factors in the emergence of a political ideology combining small-government liberalism with moral traditionalism. Historians of the New Right have demonstrated 
how women at the grassroots played a pivotal role in the development of 20th-century conservatism (McRae 2018; McGirr 2001; Nickerson 2014; Rymph 2006). Conservative opposition to New Deal liberalism produced a reinvigorated republican motherhood script that was different from its 19th-century antecedent in important ways. First, this motherhood script was forced to contend with a changed landscape of gender roles and family life. Though ostensibly opposed to feminism, conservative women nonetheless benefited from some of the advancements achieved by women's liberation. Second, this dialog with feminism produced a republican script that redefined the contours of public and private life while simultaneously reifying the distinction between the two and valorizing the white middle-class family. Finally, conservative women articulated a new form of political agency through epistemological claims about the inherent affinity between motherhood and conservatism. These epistemological claims took the form of universalized appeals to all mothers, though they were grounded in the experiences of white middle-class family life.

White motherhood underwent important transformations in the mid-20th century. After entering the workforce during World War II, white women were encouraged to return to the home and care for their families. The rise of mass media and abundance of consumer goods contributed to a valorization of the white heteronuclear family in American popular culture (Friedan 2001). At the same time, popular magazines featured profiles of women taking on a more public role as workers and community leaders (Meyerowitz 1993). Although such cultural depictions rarely challenged traditional gender roles or heterosexual marriage, they demonstrated an evolving conception of domesticity in which women could navigate between the public and private spheres while still upholding their responsibilities to their families. This dynamic allowed the heteronuclear family, and women's role within it, to achieve a mythological status, revitalizing the cult of domesticity amid liberalizing expectations of women's roles outside the home. Conservative women responded to evolving standards of women's public lives by embracing their roles as traditional caregivers and homemakers (Rymph 2006).

Women of color faced markedly different circumstances in the postwar era. Most importantly, while white working women posed a challenge to the cult of domesticity, women of color had always been an essential if undervalued component of the U.S. labor force. White families entered the middle class, buoyed by policies such as family wage standards and cheap mortgages (Katznelson 2006). Left behind in crumbling cities after periods of white flight, families of color lacked many of the economic resources or educational opportunities of white families who decamped to suburbs. In his infamous 1965 report on the status of Black families, Daniel Patrick Moynihan portrayed the prevalence of single mothers in Black families as a "tangle of pathology". His report acknowledged the role of racism in impeding Black economic achievement, noting that "the Negro community has been forced into a matriarchal structure". The problem of Black single motherhood was that it was "so out of line with the rest of the American society" and therefore "seriously retards the progress of the group as a whole" (Moynihan 1965, p. 29). Though the historical legacy of the Moynihan Report is complex, its central thesis was that the challenges facing Black Americans were partially derived from Black mothers failing to achieve the status of the white stay-at-home mother (Geary 2015; Patterson 2010).

The emergence of the women's liberation movement in the 1960s created both tensions and opportunities for conservative white women. On the one hand, feminist opposition to women's traditional roles was in direct conflict with conservative women's embrace of those roles. Inspired by Friedan (Friedan 2001) The Feminine Mystique, women formed consciousness-raising groups to highlight the drudgery and monotony of postwar family life and the burdens placed on women to maintain the home. On the other hand, women's liberation opened opportunities for women to be more active in public life. The removal of barriers to women's political activism and the increasing prominence of women in public debate created possibilities for conservative women to deepen their engagement beyond traditional channels such as women's auxiliaries and coffee klatches. Phyllis 
Schlafly demonstrated the productive tension between conservatism and feminism, and her Stop ERA movement updated the republican motherhood script at a time when women became more politically influential (Critchlow 2005). Despite her credentials and persistent presence in national politics, Schlafly treated political engagement as an extension of, rather than an alternative to, her responsibilities as a mother, and she would often begin public events by thanking her husband for letting her attend. She criticized the ERA as impeding on the rights of women as wives and mothers, often invoking her own experience as a mother in justifying her opposition. Schlafly thus leveraged a key contribution from the women's movement-the notion that personal life has political significance-in the service of decidedly anti-feminist political goals (Hemmer 2016). The development of conservative motherhood politics underscores a persistent feature of the history of women's activism during this time period: women who opposed gender equality often made use of the tools provided by previous generations of feminist activism.

The confrontation between feminism and conservative motherhood added new dimensions to the republican motherhood script. The postwar return of the cult of domesticity deepened the significance of life in the private sphere. At the same time, however, women joined the workforce, went to college, and ran for office in increasing numbers. As more conservative women became active in public life, they renegotiated the dynamic between the public and private spheres. The private life of home and family took on new political prominence as a justification to reduce the size of government and protect the (white) family from governmental intrusion. For white parents opposing bussing as a remedy to racial segregation in the 1970s, for example, the problem was that the state infringed into the private sphere of family life and supplanted parents' wishes in how to raise their children. Though their activism had the practical effect of stunting racial progress, they articulated their position as defending the family against government overreach (Formisano 1991; Lassiter 2006). The division between the two spheres remained, but white women's agency within the home became more politically salient, and women's professional lives could be meaningfully separated from life within the family.

Conservative women at the grassroots became a more influential force in the Republican Party over the course of the 20th century. They developed a conception of women's agency grounded in family responsibilities that was also responsive to changing cultural norms about women's public role. The political salience of this new republican script derived from an epistemological claim about the generalizability of white mothering experiences. Epistemological claims about women's unique "standpoint" are a recurring feature of political and social theory (e.g., Gilligan 1982; Hartsock 1983; Noddings 2002). What sets the republican script's epistemological claims apart from other feminist theories of "maternal thinking" (Ruddick 1995), however, is the specifically conservative worldview derived from being a mother. Whereas theorists like Sara Ruddick (1995) argued that mothering provides a model of a more egalitarian and peaceful world, conservative women portrayed motherhood as a necessary defense to shield the family unit from the immoral and corrupting ravages of economic and political life (Lasch 1977). Policies such as shrinking the social safety net and deregulating the economy were presented as common-sense solutions shared by a wide cross section of mothers regardless of race or socioeconomic status. Speaking in public "as a mom" allowed conservative women to universalize their relatively privileged position as middle-class mothers.

The shift from the grassroots to the mainstream of the Republican Party culminated in the nomination of Sarah Palin as vice president in 2008. Palin deployed a firebrand maternalism akin to Schlafly premised on the notion that raising children predisposed mothers to conservative values (Greenlee 2010). She characterized numerous social ills deriving from liberalism and the decline of the traditional heteronuclear family. For example, recalling the Moynihan report's claims that Black families suffered from a "tangle of pathology", she asserted that Hurricane Katrina "revealed a population of [Black] Americans dependent on government and incapacitated by the destruction of the American family" (Palin 2010, p. 114). Palin's "mama grizzly" campaign called for a "mom awakening" in 
the 2010 midterm elections to support conservative Republicans. In a video released amid the fervor of Tea Party opposition to the Obama administration, Palin characterized the epistemological claims undergirding conservative motherhood politics:

All across this country, women are standing up and speaking out for common sense solutions. These policies coming out of DC right now? This fundamental transformation of America? Well a lot of women, who are very concerned about their kids' future, are saying, "We don't like this fundamental transformation, and we're gonna do something about it." It seems like it's kind of a mom awakening in the last year and a half where women are rising up and saying, "No. We've had enough already". Because moms kind of just know when something's wrong. Here in Alaska, I always think of the mama grizzly bears rising up on their hind legs when somebody's coming to attack their cubs ... . You thought pitbulls were tough? Well, you don't want to mess with the mama grizzlies. (Mama Grizzlies 2010)

Palin successfully incorporated the republican motherhood script into the core principles of the Republican Party, and her rise demonstrated how the script had changed over the 20th century. Unlike Schlafly, Palin (2010) explicitly embraced feminism, or at least a version of feminism that stressed conservative principles such as formal (rather than substantive) equality between men and women. Her embrace of narrowly feminist discourse to support conservative causes was consistent with activism among conservative women's organizations that navigated the tension between feminism and conservatism (Schreiber 2008). Palin's "mama grizzly" politics valorized white motherhood through universalized characterizations of mothering and criticisms of non-white families.

\section{A "Profoundly Devoted Mother" Joins the Court}

The political development explored in the previous sections demonstrates how motherhood became an important ideological apparatus for conservatives to secure a racial order premised on preserving the white heteronuclear family. The revised republican motherhood script featured prominently throughout the nomination and confirmation of Amy Coney Barrett. After Trump characterized Barrett as a "profoundly devoted mother", he described her family as "a core part of who Amy is. She opened her home and her heart, and adopted two beautiful children from Haiti. Her incredible bond with her youngest child, a son with Down Syndrome, is a true inspiration". He referred to each of Barrett's children by name, thanking them for "sharing your incredible mom with our country". When it was Barrett's turn, she reiterated the themes of motherhood and family. "While I am a judge", she said, "I'm better known back home as a room parent, carpool driver, and birthday party planner". In highlighting the tender and selfless aspects of Barrett's mothering, these comments underscored the centrality of virtue in the republican motherhood script. Seated at the front row, Barrett's family reinforced the message that the future justice would be guided by her role as a mother.

Barrett's nomination event previewed a recurring theme from her confirmation hearings, where senators repeatedly invoked her role as a mother in their questions. Male Republican Senators Lindsey Graham, Chuck Grassley, Mike Lee, and John Cornyn each opened their remarks with comments about Barrett's role as a mother to seven children. Senator Josh Hawley noted that her children, seated behind her during the hearing in a republican motherhood tableau, were behaving well, and he asked if Barrett and her husband could share parenting tips. The inclusion of Barrett's husband Jesse in discussions of parenting and family life demonstrated a shift in the republican script, as "responsible fathers" involved in raising children are increasingly associated with ideal heteronuclear family life (Williams 2017). Co-parenting has become a new vehicle for fulfilling republican motherhood's charge of raising virtuous and self-sufficient children-as-future citizens, a category increasingly inclusive of girls as a result of feminist activism. When Senator John Kennedy asked, "Who does the laundry in your house?" Barrett replied that she and her husband were increasingly looking to their children to take responsibility for doing it themselves. 
In addition to shifting gender norms, the republican motherhood script has also accommodated evolving conceptions of mothers' professional roles. A debate persists as to whether working women can really "have it all", that is, a healthy home life and a fulfilling career (Szalai 2015). Some feminists have updated the materialist motherhood script to call for more investment in the services women need to be active participants in the workforce, calls made more urgent by the impact of COVID-19 on women's labor force participation (Slaughter 2012; Bateman and Ross 2020). For conservative women, however, the tension between being a mother and a professional makes women better citizens. In the hearings, Senator Joni Ernst, one of two Republican women on the Senate Judiciary Committee, characterized Democratic concern over Barrett's judicial philosophy as reflective of an opposition to traditional gender roles and religious values. Democrats, Ernst said, believed that Barrett, "a working mother of seven with a strong record of professional and academic accomplishment, couldn't possibly respect the goals and desires of today's women[.]" Ernst concluded by saying that being a Supreme Court Justice "is what a mom can do". At the same time, Ernst praised the advancements in women's rights achieved by generations of feminist activism: "The great freedom of being an American woman is that we can decide how to build our lives, whom to marry, what kind of person we are, and where we want to go". This combination of praise for domesticity with a recognition of the advance of women's rights typifies the contemporary republican motherhood script. Barrett's confirmation hearing valorized the private sphere and stressed her professional life in the public sphere while at the same time reifying the distinction between the two.

Motherhood also allowed Barrett to address political controversies around race in personal terms. Her nomination followed a tumultuous summer of protests after Minneapolis police officer Derek Chauvin murdered George Floyd. In the Senate hearing, Senator Dick Durbin asked about the impact of the video of Floyd's murder. "As you might imagine, given that I have two Black children, that was very, very personal for my family", Barrett responded. She described the events as "very difficult" for her Black daughter and remembered weeping with her. Barrett also expressed sorrow that her daughter might have to one day discuss with her own son the dangers of police brutality. She then pivoted and said that Floyd's death was also difficult for her ten-year-old white daughter, too. Barrett described her children as having the "benefit of growing up in a cocoon where they have not yet experienced hatred or violence". In this exchange, Barrett used the republican script to traverse the complicated legacy of American racism by invoking her role as a mother to Black children. She commiserated with a Black mother who must have "the talk" about police brutality with her sons as well as with white mothers grappling with the gravity and ubiquity of white supremacy (Malone Gonzalez 2019). At the same time, Barrett did not acknowledge her own positionality in contemporary debates and absolved herself of any personal responsibility to address white supremacy in her capacity as an agent of the state. "[While] I did share my personal experience and [am] very happy to discuss that the reaction our family had to the Gorge Floyd video", she said, "giving broader statements for making ... broader diagnosis about racism is ... beyond what I'm capable of doing as a judge". The racial dynamics of the updated republican motherhood script allowed Barrett to selectively deploy her role as a mother to Black children, imbuing their private conversations with political significance while eschewing a more materialist script that would call for programmatic state action to combat police brutality and white supremacy.

\section{The Constitutional Context of Universal White Motherhood}

On many occasions across her confirmation hearing, Barrett would not provide programmatic diagnoses of political problems in responses to senators' questions. Invoking her predecessor's refusal to speculate about hypotheticals in her own confirmation hearing, Barrett employed the "Ginsburg Rule" to avoid commenting on sensitive topics such as climate change and abortion. ${ }^{1}$ Beyond expressing support for judicial originalism and identifying a handful of cases she believed were correctly decided (she called the Court's 1954 decision in Brown v. Board of Education a "super precedent"), Barrett gave no hints 
as to how she would rule from the bench. The contrast between Barrett's reticence on policy matters and her candor in discussing motherhood and family life attests to the universality of white mothering in the republican motherhood script. Barrett recalled the history of white mothers' political engagement with the American state by positing that her life experiences were widely understood and generally legible.

Barrett's appeals to universal motherhood recall larger trends in conservative race jurisprudence over the last half century. As explicitly racist appeals lost political salience in the post-civil-rights era, conservative jurists adopted a logic of colorblindness to uphold a white-centered racial order (King and Smith 2005; Haney-López 2006). Much as universalized motherhood glosses over the racial specificity that has been central to materialist motherhood scripts, colorblind jurisprudence pursues legal strategies that downplay racial difference. Such strategies hold that racially targeted affirmative action policies pose a challenge to the 14th Amendment's guarantee of equal protection and, therefore, deepen the racial tensions they intend to address. For example, in a concurring opinion in a 1995 case on preferential hiring for minority-owned firms, Justice Clarence Thomas identified a "moral [and] constitutional equivalence ... between laws designed to subjugate a race and those that distribute benefits on the basis of race in order to foster some current notion of equality" (Adarand Constructors, Inc. v. Peña 1995, p. 240). Colorblindness entails a zero-sum conception of race in which the advancements of any particular racial group must, of necessity, come at the expense of another group, and efforts to remedy racial inequality are seen as unduly burdensome on white Americans.

Colorblindness as a conservative juridical philosophy, or what critical race theorists call "post-racial constitutionalism", rests on dual observations about race in contemporary America (Powell 2018). First, the notion of a "post-racial" era in American politics asserts that racism is largely a historical phenomenon, or at least a phenomenon beyond the scope of contemporary state intervention. By portraying race in this way, post-racialism strategically minimizes the enduring significance of race as an organizing principle in America. As her comments about George Floyd indicate, Amy Coney Barrett sought to update the republican motherhood script as a white mother of Black children, bringing post-racialism into the white heteronuclear family. In the hearings, Barrett demonstrated how post-racialism "serves to reinstate an unchallenged white normativity" by describing each of her children in ways that underscored the racial divisions among them (Cho 2009, p. 1592). She described her white children's accomplishments and aspirations: one child "is a sophomore in college who just might follow her parents into a career in the law", another "shares her parents' love for the liberal arts", and a third "is smart, strong, and kind, and to our delight, he still loves watching movies with Mom and Dad". Her description of her two adopted children was markedly different:

Vivian came to us from Haiti. When she arrived, she was so weak that we were told she might never walk or talk normally. She now deadlifts as much as the male athletes at our gym, and I assure you that she has no trouble talking.... John Peter joined us shortly after the devastating earthquake in Haiti, and Jesse, who brought him home, still describes the shock on JP's face when he got off the plane in wintertime Chicago. Once that shock wore off, JP assumed the happy-go-lucky attitude that is still his signature trait.

Though she portrayed her family through a post-racial lens, she nonetheless distinguished between her children through racialized tropes. The immiserated conditions of the adopted children's birthplace were presented as constitutive elements of their personalities and therefore helped to portray the Barrett household as a haven. Describing her Black daughter deadlifting "as much as the male[s]" recalled historical associations of Black women with brute strength better suited for hard labor than domesticity. Barrett's attempts to portray motherhood as transcending the politics of race reinscribed racial difference instead.

The second element of post-racial constitutionalism relates to how government should respond to racial inequality. As opposed to affirmative action efforts that identify groups suffering harm and develop programs to remedy the harm, post-racial constitutionalism 
stresses the need for facially neutral government programs that take no account of group identity. Known as proceduralism, this approach stresses the neutrality of the state in adjudicating racial discrimination. The outcomes of state action are fair only when and to the extent that the state enacts processes that remain neutral, which impedes the ability of nonwhite people to demonstrate structural discrimination (Powell 2018). This emphasis on process has replaced a deeper engagement with the substantive content of rights and equality, substituting an analysis of structural racism with a preference for ostensibly neutral procedures. As Cedric Merlin Powell (2018, p. 536) writes, "equal opportunity is essential to the legitimacy of the process, while race-conscious remedies or results should be avoided at all costs". According to this logic, "[t]he Constitution protects individuals, not racial groups; and, it protects equal opportunity not equal results, based on race".

Barrett demonstrated a commitment to proceduralism in her majority opinion in Yafai v. Pompeo (2019), deferring to immigration agency prerogative over the claims made by a Yemeni-American family. In that case, Mohshin Yafai, an American citizen, applied for a visa for his wife, Zahoor Ahmed. The visa was denied on the grounds that Ahmed had attempted to smuggle two sons into the United States, despite the couple providing evidence that the boys were dead. Upon reviewing the materials, a fraud prevention officer in the consulate ruled that Yafai and Ahmed "do not testify credibly, testify contradictorily, deny the existence of evidence, and otherwise cast doubt on the accuracy of their responses". In a 2-1 decision authored by Barrett, the Seventh Circuit upheld the visa rejection. Barrett's opinion was not based on the soundness of evidence; it was instead grounded in the doctrine of "consular nonreviewability", which "bars judicial review of visa decisions made by consular officials abroad". In order to overturn the rejection and be able to live together as a family, Yafai and Ahmed would have to demonstrate that the consular officer had acted in bad faith. Establishing bad faith entails alleging "that the consular official did not in good faith believe the information he had", and the couple failed to reach this difficult standard; the visa rejection was upheld. Though the reasons this couple elicited the consular officer's "concerns about the plaintiffs' credibility and contradictory testimony" remain unclear, their family narrative did not persuade Barrett to rule in their favor. By refusing to countenance the evidentiary claims made by Yafai and Ahmed, prioritizing instead the bureaucratic prerogative of the U.S. State Department, Barrett's opinion underscored how proceduralism authorizes the racially stratified operation of the federal state toward American families.

The republican motherhood script shares with post-racial constitutionalism an appeal to abstract universalism that entrenches the prevailing racial status quo. On a certain level, these generalizations are sensible, as they conform with political values such as fairness, equality of opportunity, and institutional rationality. In practice, however, deferring to universal tropes strategically elides the specific ways that people experience power imbalances. Failing to take into account race as an organizing principle in American politics inscribes whiteness as what George Yancy (2016, pp. 19-20; emphasis in original) calls a "transcendental norm": "whiteness takes itself to be that which remains the same across a field of difference ... [and] determines what is different without itself being defined by that system of difference". Just as post-racialism leaves white supremacy unchallenged, so too universalizing the experiences of white mothers obscures the racialized regulation of family life.

\section{Conclusions}

President Trump's selection of Amy Coney Barrett to fill the seat of Ruth Bader Ginsburg was part of a political strategy to bring suburban women voters back to the Republican Party. In the closing days of the election, opinion polling revealed sagging support for Trump's re-election among college-educated white women (Conroy et al. 2020). In response, Trump tapped into the racial logic of the republican motherhood script to drum up support from this crucial demographic using a phrase with a long history as a racial dog whistle: "law and order" (Haney-López 2014). Trump used protests against police 
brutality as evidence that American cities had fallen into chaos. In his speech accepting the Republican nomination, he painted a dark picture of "Democrat-run cities" full of "anarchists, agitators, rioters, looters, and flag-burners". He used cataclysmic rhetoric to stoke white suburban women's fears, claiming that Democrats "will demolish the suburbs" if they get into power. At a campaign stop, he made his appeals to these voters explicit: "Suburban women, will you please like me?" (Trump 2020a).

Trump's "law and order" appeals to suburban women and Amy Coney Barrett's repeated references to motherhood shared a common political goal: upholding the prevailing, white-centered racial order. The political development of motherhood and race in America demonstrates how maternal rhetoric operates as an ideological mechanism for cohering and enforcing a racial order predicated on enshrining the white heteronuclear family. Rather than taking place "outside" politics in the mythical private sphere, motherhood is itself a site for regulating the politics of race in the material reality of day-to-day life. It describes an operation of power that distinguishes good and bad mothers and allocates resources accordingly. Attending to the political development of motherhood over time can help to demystify the processes through which family continues to structure race in America. It may also contribute to the salience of alternative materialist scripts that can help to improve the lives of American families.

Funding: This research received no external funding

Institutional Review Board Statement: Not applicable.

Informed Consent Statement: Not applicable.

Data Availability Statement: Not applicable.

Acknowledgments: The author would like to thank Alison Gash for editing and coordinating this special issue and three anonymous reviewers for their generous feedback. Thanks also to Chelsea Ebin, J. Ricky Price, Jack Vimo, and the participants at the 2021 American Politics Group annual conference at the University of Kent (UK) for their comments on an earlier draft of this article.

Conflicts of Interest: The author declares no conflict of interest.

\section{Notes}

1 At her confirmation, Justice Ginsburg's said she "can offer no forecasts, no hints for that would show not only disregard for the specifics of the particular case, it would display disdain for the entire judicial process." The so-called "Ginsburg Rule" is regularly invoked in Senate confirmation hearings. The eponymous source of the "rule" did not originate the concept, however, and it is currently more frequently invoked as a way to avoid going on the record on issues that the Court might decide (Ringhand and Collings 2018).

\section{References \\ Cases}

Adarand Constructors, Inc. v. Peña. 1995. 515 U.S. 200.

Yafai v. Pompeo. 2019. No. 18-1205 (7th Cir. 2019).

\section{Other Sources}

Alphonso, Gwendoline. 2018. Polarized Families, Polarized Parties: Contesting Values and Economics in American Politics. Philadelphia: University of Pennsylvania Press.

Alphonso, Gwendoline, and Richard Bensel. 2020. The Legal Construction of Motherhood and Paternity: Interracial Unions and the Color Line in Antebellum Louisiana. In Stating the Family: New Directions in the Study of American Politics. Edited by Julie Novkov and Carol Nackenoff. Lawrence, KY: University Press of Kansas, pp. 97-126.

Bateman, Nicole, and Martha Ross. 2020. Why Has COVID-19 Been Especially Harmful for Working Women? Washington, DC: Brookings Institute, Available online: https://www.brookings.edu/essay/why-has-covid-19-been-especially-harmful-forworking-women/ (accessed on 15 February 2021).

Block, Melissa. 2020. The Politics at Play in Judge Amy Coney Barrett's Confirmation Hearings. National Public Radio. October 14. Available online: https:/ / www.npr.org/2020/10/09/922185750/the-politics-at-play-in-judge-amy-coney-barretts-confirmationhearings (accessed on 15 February 2021). 
Cantor, Julie. 2020. The 'Mominee': Supreme Expectations and Gender Bias in Amy Coney Barrett's Confirmation. The National Law Journal. October 26. Available online: https://www.law.com/nationallawjournal/2020/10/26/the-mominee-supremeexpectations-and-gender-bias-in-amy-coney-barretts-confirmation/ (accessed on 15 February 2021).

Carby, Hazel. 1987. Reconstructing Womanhood: The Emergence of the Afro-American Woman Novelist. Oxford: Oxford University Press.

Chadsey, Mildred. 1915. Municipal Housekeeping. The Journal of Home Economics 7: 53-59.

Cho, Sumi. 2009. Post-Racialism. Iowa Law Review 94: 1589-645.

Conroy, Meredith, Amelia Thomson-DeVeaux, and Erin Cassese. 2020. Why Trump Is Losing White Suburban Women? FiveThirtyEight. Available online: https:/ / fivethirtyeight.com/features/why-trump-is-losing-white-suburban-women/ (accessed on 15 February 2021).

Critchlow, Donald T. 2005. Phyllis Schlafly and Grassroots Conservatism: A Woman's Crusade. Princeton: Princeton University Press.

De Tocqueville, Alexis. 2003. Democracy in America: And Two Essays on America. London: Penguin Books Limited.

Deason, Grace, Jill S. Greenlee, and Carrie A. Langner. 2015. Mothers on the Campaign Trail: Implications of Politicized Motherhood for Women in Politics. Politics, Groups, and Identities 3: 133-48. [CrossRef]

Formisano, Ronald P. 1991. Boston against Busing: Race, Class, and Ethnicity in the 1960s and 1970s. Chapel Hill: University of North Carolina Press.

Friedan, Betty. 2001. The Feminine Mystique. New York: W. W. Norton, First publish in 1963.

Geary, Daniel. 2015. Beyond Civil Rights: The Moynihan Report and Its Legacy. Philadelphia: University of Pennsylvania Press, Incorporated.

Gilligan, Carol. 1982. In A Different Voice. Cambridge: Harvard University Press.

Greenlee, Jill S. 2010. Soccer Moms, Hockey Moms and the Question of 'Transformative' Motherhood. Politics and Gender 6: 405-31. [CrossRef]

Greenlee, Jill S. 2014. The Political Consequences of Motherhood. Ann Arbor: University of Michigan Press.

Haney-López, Ian. 2006. White by Law: The Legal Construction of Race, 2nd ed. New York: NYU Press.

Haney-López, Ian. 2014. Dog Whistle Politics: How Coded Racial Appeals Have Reinvented Racism and Wrecked the Middle Class. Oxford: Oxford University Press.

Hartsock, Nancy C. M. 1983. The Feminist Standpoint: Developing the Ground for a Specifically Feminist Historical Materialism. In Discovering Reality: Feminist Perspectives on Epistemology, Metaphysics, Methodology, and Philosophy of Science. Edited by Sandra Harding and Merrill B. Hintikka. Dordrecht: Springer, pp. 283-310.

Hemmer, Nicole. 2016. What Phyllis Schlafly Owes Feminism. Politico Magazine. September 6. Available online: https:/ / www.politico. com/magazine/story/2016/09/phyllis-schlafly-death-housewife-activism-feminism-214213 (accessed on 15 February 2021).

Higginbotham, Evelyn Brooks. 1994. Righteous Discontent: The Women's Movement in the Black Baptist Church, 1880-1920. Cambridge: Harvard University Press.

Jones, Jacqueline. 2010. Labor of Love, Labor of Sorrow: Black Women, Work, and the Family, from Slavery to the Present. New York: Basic Books.

Jones-Rogers, Stephanie E. 2019. They Were Her Property: White Women as Slave Owners in the American South. New Haven: Yale University Press.

Katznelson, Ira. 2006. When Affirmative Action Was White: An Untold History of Racial Inequality in Twentieth-Century America. New York: W. W. Norton.

Keating, Shannon. 2020. Amy Coney Barrett and the Cult of Conservative White Motherhood. Buzzfeed. October 16. Available online: https:/ / www.buzzfeednews.com/article/shannonkeating/amy-coney-barrett-and-the-weaponization-of-whitemotherhood (accessed on 15 February 2021).

Kerber, Linda. 1976. The Republican Mother: Women and the Enlightenment-An American Perspective. American Quarterly 28: 187-205. [CrossRef]

Kerber, Linda. 1980. Women of the Republic: Intellect and Ideology in Revolutionary America. Durham: UNC Press Books.

King, Desmond S., and Rogers M. Smith. 2005. Racial Orders in American Political Development. American Political Science Review 99: 75-92. [CrossRef]

Lasch, Christopher. 1977. Haven in a Heartless World: The Family Besieged. New York City: Norton.

Lasch-Quinn, Elisabeth. 1993. Black Neighbors: Race and the Limits of Reform in the American Settlement House Movement, $1890-1945$. Chapel Hill: University of North Carolina Press.

Lassiter, Matthew D. 2006. The Silent Majority: Suburban Politics in the Sunbelt South. Princeton: Princeton University Press.

Lawson, Erica S. 2018. Bereaved Black Mothers and Maternal Activism in the Racial State. Feminist Studies 44: 713-35. [CrossRef]

Malone Gonzalez, Shannon. 2019. Making It Home: An Intersectional Analysis of the Police Talk. Gender E Society 33: $363-86$.

Mama Grizzlies. 2010. SarahPAC, video, June 23. Available online: https:/ / youtu.be/fsUVL6ciK-c (accessed on 15 February 2021).

McGirr, Lisa. 2001. Suburban Warriors: The Origins of the New American Right. Princeton: Princeton University Press.

McRae, Elizabeth Gillespie. 2018. Mothers of Massive Resistance: White Women and the Politics of White Supremacy. Oxford: Oxford University Press.

Meyerowitz, Joanne. 1993. Beyond the Feminine Mystique: A Reassessment of Postwar Mass Culture, 1946-1958. The Journal of American History 79: 1455-82. [CrossRef] 
Miller, Claire Cain, and Alisha Haridasani Gupta. 2020. Why 'Supermom' Gets Star Billing on Résumés for Public Office. The New York Times. October 14. Available online: https://www.law.com/nationallawjournal/2020/10/26/the-mominee-supremeexpectations-and-gender-bias-in-amy-coney-barretts-confirmation/ (accessed on 15 February 2021).

Mink, Gwendolyn. 1995. The Wages of Motherhood: Inequality in the Welfare State, 1917-1942. Ithaca: Cornell University Press. Moynihan, Daniel Patrick. 1965. The Negro Family: The Case for National Action; Washington: US Government Printing Office. Muncy, Robyn. 1991. Creating a Female Dominion in American Reform, 1890-1935. Oxford: Oxford University Press.

Nickerson, Michelle M. 2014. Mothers of Conservatism: Women and the Postwar Right. Princeton: Princeton University Press.

Noddings, Nel. 2002. Starting at Home: Caring and Social Policy. Berkeley: University of California Press.

Novkov, Julie. 2008. Racial Union: Law, Intimacy, and the White State in Alabama, 1865-1954. Michigan: University of Michigan Press.

Novkov, Julie, and Carol Nackenoff. 2020. Stating the Family: New Directions in the Study of American Politics. Lawrence: University Press of Kansas.

Omi, Michael, and Howard Winant. 2014. Racial Formation in the United States. New York: Taylor \& Francis.

Palin, Sarah. 2010. America by Heart: Reflections on Family, Faith, and Flag. New York: Harper Collins.

Patterson, James T. 2010. Freedom Is Not Enough: The Moynihan Report and America's Struggle over Black Family Life-From LBJ to Obama. New York: Basic Books.

Powell, Cedric Merlin. 2018. The Rhetorical Allure of Post-Racial Process Discourse and the Democratic Myth. Utah Law Review $2018: 523$. Ringhand, Lori A., and Paul M. Collings. 2018. Neil Gorsuch and the Ginsburg Rules. Chicago-Kent Law Review 93: 475-504.

Roberts, Dorothy E. 2004. Black Club Women and Child Welfare: Lessons for Modern Reform. Florida State University Law Review 32: 957. Ruddick, Sara. 1995. Maternal Thinking: Toward a Politics of Peace. Boston: Beacon Press.

Rymph, Catherine E. 2006. Republican Women: Feminism and Conservatism from Suffrage through the Rise of the New Right. Chapel Hill: University of North Carolina Press.

Schreiber, Ronnee. 2008. Righting Feminism: Conservative Women and American Politics. Oxford: Oxford University Press.

Skocpol, Theda. 1992. Protecting Soldiers and Mothers. Cambridge: Harvard University Press.

Slaughter, Anne-Marie. 2012. Why Women Still Can't Have It All. The Atlantic, July/August.

Smith, Rogers M., and Desmond King. 2020. White Protectionism in America. Perspectives on Politics, 1-19. [CrossRef]

Strach, Patricia. 2006. The Politics of Family. Polity 38: 151-73. [CrossRef]

Szalai, Jennifer. 2015. The Complicated Origins of ‘Having It All'. The New York Times, January 2.

Trump, Donald J. 2020a. Campaign Rally in Johnstown, PA. Available online: https:/ /www.youtube.com/watch?v=CpDA4TB0BiE (accessed on 19 February 2021).

Trump, Donald J. 2020b. Remarks on the Nomination of Amy Coney Barrett to Be a United States Supreme Court Associate Justice. Washington: The American Presidency Project, Available online: https:/ / www.presidency.ucsb.edu/documents/remarks-the-nominationamy-coney-barrett-be-united-states-supreme-court-associate-justice (accessed on 17 February 2021).

Vandenberg-Daves, Jodi. 2014. Modern Motherhood: An American History. New Brunswick: Rutgers University Press.

Welter, Barbara. 1966. The Cult of True Womanhood: 1820-1860. American Quarterly 18: 151-74. [CrossRef]

Williams, H. Howell. 2017. 'Personal Responsibility' and the End of Welfare as We Know It. PS, Political Science E Politics 50: $379-83$. Yancy, George. 2016. Black Bodies, White Gazes: The Continuing Significance of Race in America. New York: Rowman \& Littlefield. 